\title{
PHYSICAL AND MECHANICAL PROPERTIES OF CANTALOUPE "CHARENTAIS" FRUITS APPLIED TO DESIGN SEED-EXTRACTOR
}

\author{
A. M. El Lithy ${ }^{(*)}$
}

\section{ABSTRACT}

The aim of this research is to study some physical and mechanical properties of cantaloupe "charentais" variety that provide the basic data for the proper design of handling-machines. The tested physical and mechanical properties were incorporated in the design of the seedextraction machine as a case study.

The main results in this study can be summarized as follows:

Physical properties of cantaloupe fruits: diameter $=81.99-112.16 \mathrm{~mm}$, height $=66.69-127.55 \mathrm{~mm}$, geometric diameter $=83.5-117.31 \mathrm{~mm}$, mass $=332-902 \mathrm{~g}$, volume $=345-1000 \mathrm{~cm}^{3}$, projected area $=85.21-$ $173.79 \mathrm{~cm}^{2}$, real density $=0.87-1.00 \mathrm{~g} / \mathrm{cm}^{3}$, bulk density $=0.695 \mathrm{~g} / \mathrm{cm}^{3}$, sphericity $=0.84-1.18$.

Mechanical properties: maximum rolling-angle was 20 - 25 degree, minimum rolling-angle was $12-20$ degree and the average firmness of cantaloupe-fruit was $85.71 \mathrm{~N} / \mathrm{cm}^{2}$.

The physical and mechanical properties are incorporated in the design of the cantaloupe-fruit hopper size and wall angle, convey belt with pressing fingers, pressing mechanism and separation mechanism (vibrated chainbelt) of the proposed design idea of seed-extraction machine is given also in the paper as a case study.

\section{INTRODUCTION}

antaloupe (Cucumis melo) is a subtropical fruits and belongs to family Cucurbitaceae. Cantaloupe is considered as one of the best fruits due to its high nutritive value. Besides a rich source of vitamin $\mathrm{A}$ and $\mathrm{C}$, it contains a fair amount of nutrients (calcium,

(*) Assoc. Prof., Ag. Eng. Dept., Col. of Ag., Al -Azhar U., Assiut. 
magnesium, phosphorus, potassium and iron) and vitamins B1, B3 and B5. Arabsalmani (1996). Cantaloupe is the major horticultural crop in Egypt. The cultivated area of cantaloupe is 74.147 thousand feddans (31.14 thousand hectare) in 2009 and the annual production is about 755.6 thousand ton in 2009. Ministry of Agriculture (2009).

Many authors \{Akubuo and Odigboh (1999), Abou-Elmagd, et al. (2002), Awady et al. (2004), El Sayed et al. (2009) and Yehia et al. (2009)\} mentioned that the knowledge of the physical and mechanical characteristics of agricultural products is important in the design, of agricultural machines and equipment. They studied the physical properties and characteristics of some agricultural crops and fruits, which can be used in the design and development of equipment. Abou-Elmagd, et al. (2006) designed and tested a crushing machine for watermelon seeds-extraction. The machine consists of hopper, crushing drum with knives, screw conveyer and water source.

Ghanbarian et al. (2008) found that the average masses of cantaloupe fruits were 697 to $1272 \mathrm{~g}$, the fruit volumes were 1084 and $1409 \mathrm{~cm}^{3}$ and geometric mean diameters were 11.7 and $13.12 \mathrm{~cm}$ for Samsouri and shahabadi varieties respectively.

Rashidi and Seyfi (2007) found that the mass of cantaloupe fruit (Samsouri variety) ranges from about 510 to $3380 \mathrm{~g}$, the fruit volume from 538 to $3654 \mathrm{~cm}^{3}$ and the length from 95 to $185 \mathrm{~cm}$, Major diameter from 106 to $205 \mathrm{~cm}$, Minor diameter from 101 to $190 \mathrm{~cm}$ and density from 0.78 to $1.07 \mathrm{~g} / \mathrm{cm}^{3}$.

Hassan (1994) reported that the methods of extracting vegetable seeds from soft fruits include the following steps: 1) Cutting and smashing the fruits mechanically as in tomatoes and watermelons or cutting them into two-halves manually using a knife as in sweet melon. 2) Extracting seeds from surrounding gelatin and smashed fruit parts by leaving the mixture from 2 to 4 days to ferment as in tomatoes or proceeding extraction mechanically as in pepper, eggplant and tomato. 3) Washing seed using running water. 4) Drying seeds naturally in drying climate or by exposing them to current of warm air in humid climate.

Vergano et al. (1992) studied the design aspects and performance of an axial-flow vegetable seed extracting machine. They compared the manual 
with the mechanical seed extraction for different vegetable fruits. They found that the manual seed extraction output was $0.47,1.20,1.26,1.56$, $1.83,2.20$ and $3.14 \mathrm{~kg} / \mathrm{man}-\mathrm{h}$ for cucumber, watermelon, tomato, summer squash, brinjal, squash melon and chillies, respectively. Meanwhile, the productivity of the seed extracting machine varied from 310 to $1930 \mathrm{~kg} / \mathrm{h}$ for all investigated vegetable fruits. They added that germination count for mechanically extracted seeds was higher than for the manually extracted seeds.

Yehia et al. (2010) studied some physical and mechanical properties of cantaloupe "Galia" variety. The main results in this study were: Physical properties of cantaloupe fruits: diameter $=82.12-113.51 \mathrm{~mm}$, height $=$ $82.07-119.95 \mathrm{~mm}$, mass $=329.2-940.6 \mathrm{~g}$, volume $=380-860 \mathrm{~cm}^{3}$, projected area $=85.85-160.95 \mathrm{~cm}^{2}$, real density $=0.69-1.08 \mathrm{~g} / \mathrm{cm}^{3}$, bulk density $=0.51 \mathrm{~g} / \mathrm{cm}^{3}$, sphericity $=0.88-1.07$. Mechanical properties: the average of cantaloupe-fruit firmness was $62.5 \mathrm{~N} / \mathrm{cm}^{2}$, the maximum $=80.4 \mathrm{~N} / \mathrm{cm}^{2}$ and the minimum $=28.6 \mathrm{~N} / \mathrm{cm}^{2}$.

The objective of the present research is to study some physical and mechanical properties of cantaloupe fruits, as a data base, to help the design of handling machines. The physical and mechanical properties are incorporated in the design of the seed-extraction machine as a case study.

\section{MATERIALS AND METHODS}

a. Fruits.: Cantaloupe crop "Charentais" variety was considered in this study. All measurements were done using a random sample of 100 fruits. The samples were taken randomly from cantaloupe trees (private farm in El Sharkia Governorate (محافظة الثرقية) at acceptable harvesting date) and from "El Oboor" (سوق العبور) Market; and the measurements were taken in the same day.

\section{b. Instrumentation:}

b1. Digital caliper with vernier: with accuracy of $0.01 \mathrm{~mm}$, to measure different dimensions of cantaloupe fruits.

b2. Digital balance: with accuracy of $0.2 \mathrm{~g}$, to measure mass of cantaloupe fruits.

b3. Graduated cylinder: of $2000 \mathrm{~mL}$ with accuracy of $25 \mathrm{~mL}$ to determine the real density and volume of fruit by immersion in water. 
b4. Friction and repose angle measurement: The friction angle was measured by placing a bounded group of fruits together (sample of (4) fruits) on a horizontal surface and gradually increasing the angle of inclination until the fruits begin sliding without rolling. The repose angle (internal friction) was measured by placing two bounded groups of fruits above each other and gradually increasing the angle of inclination until the upper group begin sliding without rolling.

b5. Rolling angle measurement: The fruits are placed on a horizontal surface one by one then the angle of inclination is gradually increased until the fruits begin to roll. For each fruit of an average sample (50), two angles of rolling are determined: for the maximum stable (with their base down) and minimum stable positions.

b.6 Penetrometer: Penetrometer, made in Italy, with accuracy of $0.1 \mathrm{~N}$ was used to measure penetration force of cantaloupe fruits. The firmness of fruit was obtained by dividing the penetration force by the area $(0.28$ $\mathrm{cm}^{2}$ ) of cylindrical probe with circular edge, which had $0.6 \mathrm{~cm}$ diameter.

\section{c. Equations and calculations:}

The following equations were used to calculate sphericity, projected area and real density according to Mohsenin, 1986 and Wilhelm et al., 2005 Sphericity ratio $=\mathrm{D} / \mathrm{H}$

Where: $\mathrm{H}=$ Fruit height, $\mathrm{mm}$ and $\mathrm{D}=$ Diameter of fruit, $\mathrm{mm}$ (fig. 1).

Projected area $=4 / \pi(D * H)$

Real density $=$ Mass $/$ Volume

Geometric diameter $=\left(D_{1} \times D_{2} \times H\right)^{1 / 3}$
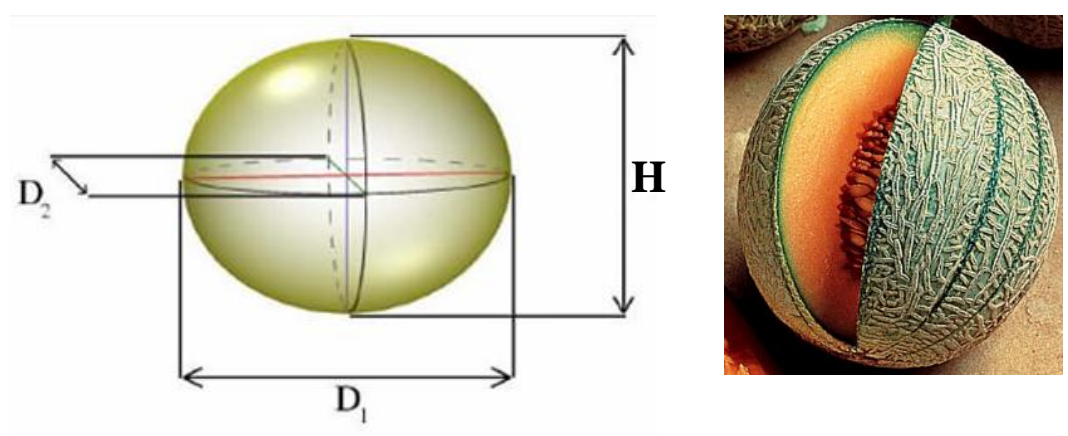

$\mathrm{D}=\mathrm{D}_{1}=\mathrm{D}_{2}$ for studied varieties

Fig. 1: View and photograph of cantaloupe fruit. 


\section{d. The designed seed-extraction machine:}

Fig. 2 shows a schematic diagram of a design-idea of cantaloupe seedextraction machine. Parameters shown on the figure are essentially those to be determined for cantaloupe through this work, for design the seedextraction machine.

\section{Fruit hopper}

(2), (3), (4)

Vibrated chain belt

(1), (2), (3),

(4), (5), (6)

Fruit half

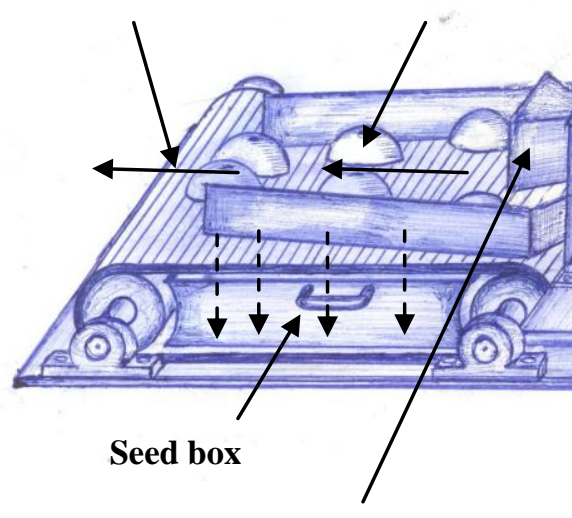

Fixed knife and two wings

(1), (5)

Convey and belt with press fingers

(1), (2), (4), (5)

$\longrightarrow \quad$ Half - fruit movement direction

$----\rightarrow$ Seed movement direction

Fig. 2: Diagram demonstrating idea of extracting machine, with the numbers in brackets indicating parameters necessary for design of different parts.

\section{Associated parameters:}

(1) Fruit dimensions, (2) Bulk density, (3) Friction and rolling angles,

(4) Fruit mass, (5) Fruit firmness, and (6) Seed size. 


\section{RESULTS AND DISCUSSION}

\section{a. Physical properties of cantaloupe fruits.}

Table 1 shows dimensions, sphericity, mass, volume, real density, projected area, mass, juice volume, seed number per fruit and bulb thickness of cantaloupe (Charentais variety). These data were measured on 100 fruit sample, according to the standards set in (Mohsenin, 1986 and Wilhelm et al., 2005).

Table 1: Physical properties of cantaloupe fruits (Charentais variety).

\begin{tabular}{|l|c|c|c|c|c|}
\hline Physical properties & Min. & Max. & Average & S. D. $^{(1)}$ & C. V. $^{(2)}$ \\
\hline Diameter, mm & 81.99 & 112.16 & 95.24 & 6.54 & 6.87 \\
\hline Height, mm & 66.69 & 127.55 & 94.41 & 11.22 & 11.88 \\
\hline $\begin{array}{l}\text { Geometric diameter, } \\
\mathrm{mm}\end{array}$ & 83.5 & 117.31 & 94.83 & 7.87 & 8.30 \\
\hline Sphericity & 0.84 & 1.18 & 1.00 & 0.07 & 6.61 \\
\hline Mass, g & 332 & 902 & 515.71 & 138.56 & 26.87 \\
\hline Volume, $\mathrm{cm}^{3}$ & 345 & 1000 & 541.20 & 155.66 & 28.76 \\
\hline Bulk density, g/cm & \multicolumn{5}{|l|}{0.695} \\
\hline Real density, g/cm & 0.87 & 1.00 & 0.96 & 0.04 & 4.06 \\
\hline Projected area, cm ${ }^{2}$ & 85.21 & 173.79 & 115.04 & 20.04 & 17.42 \\
\hline No. of seeds/fruits & 419 & 561 & 468 & 16.28 & 15.16 \\
\hline Bulb thickness, cm & 3 & 3.5 & 3.22 & 4.22 & 5.12 \\
\hline
\end{tabular}

(1) S. D. is standard deviation.

(2) C. V. is coefficient of variation.

\section{a1. Dimensions of fruit:}

Fig. 3 indicates that the fruit diameter, height and geometric diameter ranges of sample were 81.99 - $112.16 \mathrm{~mm}$ (average $95.24 \mathrm{~mm}$ ), 66.69 $127.55 \mathrm{~mm}$ (average $94.41 \mathrm{~mm}$ ) and $83.5-117.31 \mathrm{~mm}$ (average 94.83 $\mathrm{mm}$ ) respectively. The most frequent percent $(96 \%)$ of cantaloupe fruits in the sample have $90-110 \mathrm{~mm}$ diameter, $(86 \%)$ of cantaloupe fruits in the sample have $90-110 \mathrm{~mm}$ height and $(92 \%)$ of cantaloupe fruits in the sample have $90-110 \mathrm{~mm}$ geometric diameter.

\section{a2. Shape and size of fruit:}

If sphericity is less than 0.9 , the fruit belongs to oblate group; if sphericity is greater than 1.1, it belongs to oblong group. The remaining fruits with 
intermediate index values are considered to be round (Buyanov and Voronyuk, 1985).

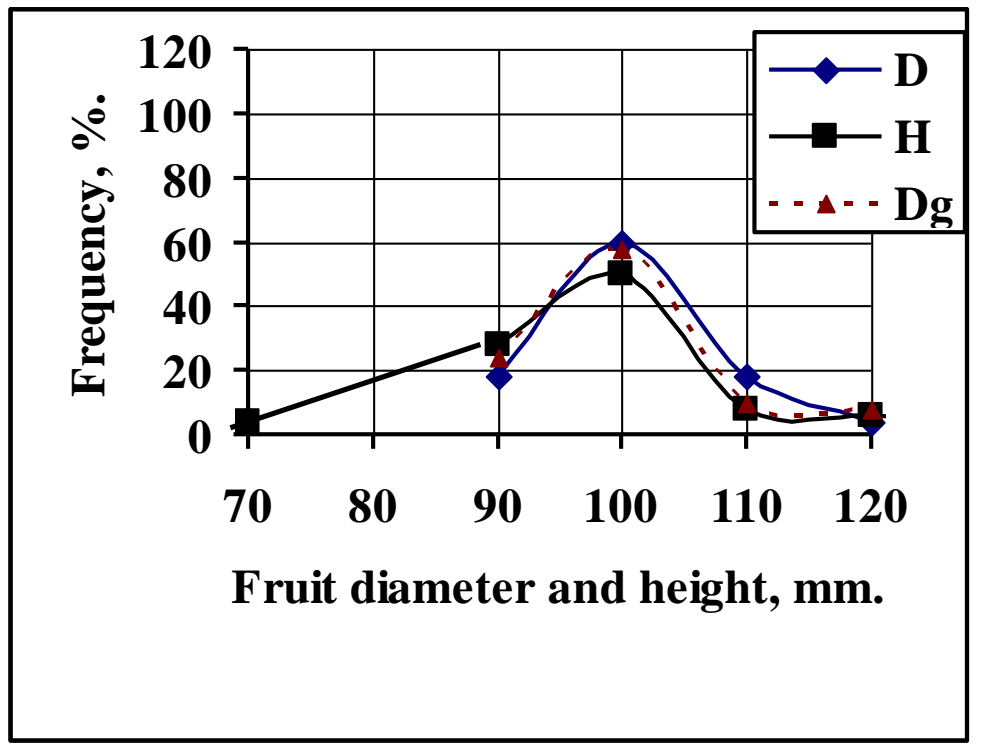

Fig. 3: Frequency curves distribution of fruit dimensions (diameter "D" , geometric diameter " $\mathrm{D}_{\mathrm{g}}$ "and height "H") of cantaloupe fruits (Charentais variety).

Fig. 4 indicates that the fruit spericity ranged in sample between 0.84 and 1.18. The most frequent percent (96\%) of cantaloupe fruits in the sample was round (sphericity $0.9-1.1)$ and $(4 \%)$ of cantaloupe fruits in the sample were oblong (sphericity > 1.1).

\section{a3. Mass and volume of fruit:}

Fig. 5 indicates that the fruit mass and volume ranges of sample were 332 - $902 \mathrm{~g}$ (average $514.83 \mathrm{~g}$ ) and $345-1000 \mathrm{~cm}^{3}$ (average $540.25 \mathrm{~cm}^{3}$ ) respectively. The most frequent percent $(80 \%)$ of cantaloupe fruits in the sample had 400 - $600 \mathrm{~g}$ mass and $(80 \%)$ had $400-600 \mathrm{~cm}^{3}$ volume.

\section{a4. Real density of fruit:}

The fruit real density of sample ranged between 0.87 and $1.0 \mathrm{~g} / \mathrm{cm}^{3}$ (average $0.90 \mathrm{~g} / \mathrm{cm}^{3}$ ). The most frequent percent $(100 \%)$ of cantaloupe fruits in the sample had $0.87-1.00 \mathrm{~g} / \mathrm{cm}^{3}$ real density. 


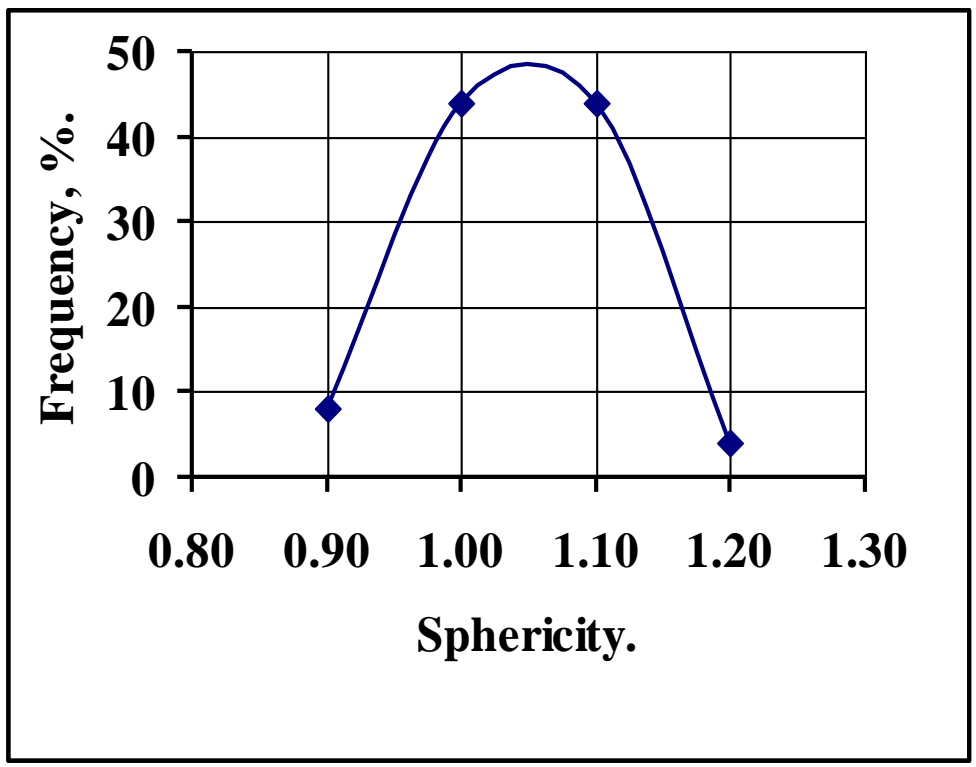

Fig. 4: Frequency distribution of fruit sphericity of cantaloupe fruits (Charentais variety).

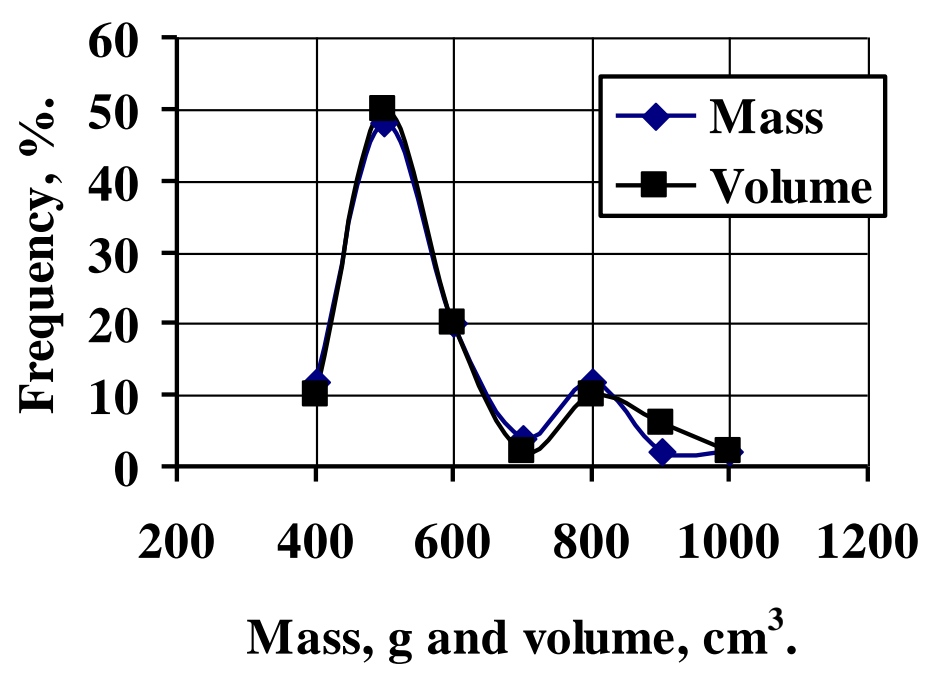

Fig. 5: Frequency curves distribution of fruit mass and volume of cantaloupe fruits (Charentais variety). 


\section{a5. Projected area of fruit:}

Fig. 6 indicates that the fruit projected area of sample ranged between 85.21 and $173.79 \mathrm{~cm}^{2}$ (average $115.04 \mathrm{~cm}^{2}$ ). The most frequent percent $90 \%$ ) of cantaloupe fruits in the sample have $100-140 \mathrm{~cm}^{2}$ projected area.

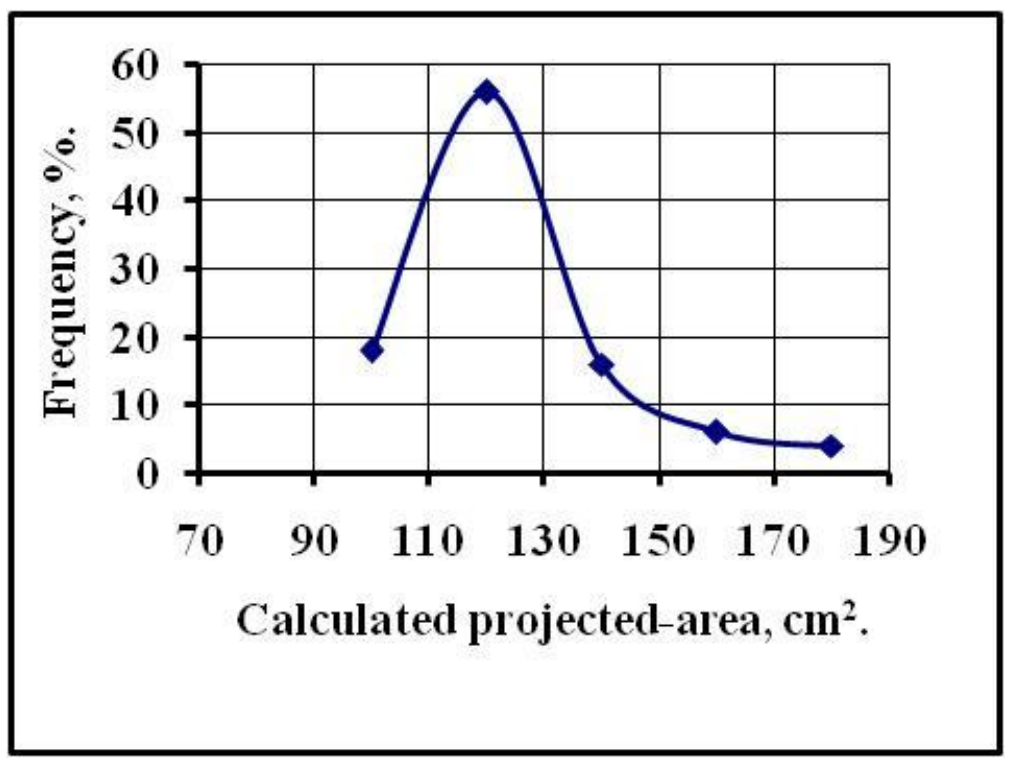

Fig. 6: Frequency curve distribution of fruit projectedarea of cantaloupe fruits (Charentais variety).

\section{b. Mechanical properties of cantaloupe fruits.}

\section{b1. Friction, rolling and repose angles of cantaloupe fruits:}

Table 2 shows friction and rolling angles of cantaloupe fruits. The maximum friction angle (28 - 34 degree) and the maximum rolling-angle ranges (23 - 25 degree) were obtained with wood surface. Whereas, the minimum ranges of friction and rolling angles $(9-12$ and $11-18$ respectively) were obtained with aluminum surface. The average reposeangle was about 32.5 degree. 
Table 2: Friction and rolling angles for cantaloupe fruits (Charentais variety) with different surface types.

\begin{tabular}{|c|c|c|c|c|c|c|c|c|c|}
\hline \multirow{2}{*}{$\begin{array}{c}\text { Surface } \\
\text { type }\end{array}$} & \multicolumn{3}{|c|}{$\begin{array}{c}\text { Friction angle, } \\
\text { degree }\end{array}$} & \multicolumn{5}{c|}{ Rolling angle, degree } \\
\cline { 2 - 10 } & Max. & Min. & Av. & Max. & Min. & Av. & Max. & Min. & Av. \\
\hline Wood & 34 & 28 & 30 & 25 & 23 & 24 & 21 & 18 & 20 \\
\hline Metal & 12 & 10 & 10.3 & 25 & 20 & 22.7 & 20 & 12 & 15.7 \\
\hline Galv. I. & 12 & 10 & 10.7 & 25 & 20 & 22.8 & 20 & 12 & 15.2 \\
\hline Alum. & 12 & 9 & 10.4 & 23 & 15 & 20.1 & 18 & 11 & 12.8 \\
\hline SS & 12 & 10 & 10.5 & 25 & 15 & 20.2 & 19 & 12 & 12.9 \\
\hline
\end{tabular}

Wood: wood sheet No. 2; Galv. I.: Galvanized iron; Alum.: Aluminium; and SS.: Stainless steal.

\section{b2. Firmness of cantaloupe fruits:}

The cantaloupe-fruit firmness was $85.71 \mathrm{~N} / \mathrm{cm}^{2}$.

\section{c. Application of the theory to the design of the cantaloupe seed- extraction machine:}

Parameters required for design of seed-extraction machine have been explained in the part $2 \mathrm{~d}$ in the section on "Materials and Methods". Fig. 2 shows the parameters. The physical and mechanical properties are incorporated in the design of the cantaloupe-fruit hopper, convey belt with pressing fingers and separated mechanism (vibrated chain-belt) of the designed seed-extraction machine as follows:

\section{Design of fruit hopper and bin (Fig. 2):}

Fruit-hopper dimensions $=60 \times 60 \times 40 \mathrm{~cm}$.(about $10-12 \mathrm{~kg}$. fruit capacity) Fruit-hopper tilt angle $=$ more than maximum friction angle between cantaloupe fruits and stainless steal surface $=$ more than $25^{\circ}$.

Fruit bin width $=$ more than maximum fruit diameter and height $=130 \mathrm{~mm}$. Fruit-bin tilt angle $=$ more than maximum friction angle between cantaloupe fruits and stainless steal surface $=$ more than $25^{\circ}$.

\section{Design of convey belt and pressing fingers:}

Convey-belt width $=$ more than maximum diameter of cantaloupe fruits $=$ $200 \mathrm{~mm}$.

Pressing-fingers height $=$ more than the maximum height $=$ about $15 \mathrm{~cm}$. 
No. of pressing fingers $=2$ fingers .

\section{Design of separated mechanism:}

Vibrated-chain belt width $=$ more than maximum diameter of cantaloupe

$$
\text { fruits }=200 \mathrm{~mm} \text {. }
$$

Distance between rods of chain belt $=$ more than seed size $=$ about $10 \mathrm{~mm}$.

\section{CONCLUSION}

The main results in this study can be summarized as follows:

Physical properties of cantaloupe fruits: diameter $=81.99-112.16 \mathrm{~mm}$, height $=66.69-127.55 \mathrm{~mm}$, geometric diameter $=83.5-117.31 \mathrm{~mm}$, mass $=332-902 \mathrm{~g}$, volume $=345-1000 \mathrm{~cm}^{3}$, projected area $=85.21-$ $173.79 \mathrm{~cm}^{2}$, real density $=0.87-1.00 \mathrm{~g} / \mathrm{cm}^{3}$, bulk density $=0.695 \mathrm{~g} / \mathrm{cm}^{3}$, sphericity $=0.84-1.18$. Mechanical properties: maximum rolling-angle was $20-25$ degree, minimum rolling-angle was $12-20$ degree and the average of cantaloupe-fruit firmness was $85.71 \mathrm{~N} / \mathrm{cm}^{2}$.

The physical and mechanical properties are incorporated in the design of the cantaloupe-fruit hopper, convey belt with pressing fingers and separated mechanism (vibrated chain-belt) of the designed seedextraction machine as follows:

Design of fruit hopper: Fruit-hopper dimensions $=60 \times 60 \times 40 \mathrm{~cm}$. Fruit-hopper tilt angle $=$ more than maximum friction angle between cantaloupe fruits and stainless steal surface $=$ more than $25^{\circ}$.

Design of convey belt and pressing fingers: Convey-belt width $=$ more than maximum diameter of cantaloupe fruits $=200 \mathrm{~mm}$. Pressing-fingers height $=$ more than the maximum height $=$ about $15 \mathrm{~cm}$. No. of pressing fingers $=2$ fingers.

Design of separated mechanism: Vibrated-chain belt width $=$ more than maximum diameter of cantaloupe fruits $=200 \mathrm{~mm}$. Distance between rods of chain belt $=$ more than seed size $=$ about $10 \mathrm{~mm}$.

\section{REFERENCES}

Abou-Elmagd, A.E., Hamam, A. S., EL-Saadany, M. A. and ElKawaga, S. A., 2002, Design of a cone-end detacher for orange picking, Misr. J. Ag. Eng. 19(2): 491-507. 
Abou-Elmagd, A.E., Abd El-Mageed, H. N., Baiomey, M. A., and Sayed-Ahmed, I. F., 2006, Proper design and evaluation of an equipment for extracting watermelon seeds, J. Agric Sci. Mansoura Univ., 31(7): 53-68.

Akubuo, C. O. and Odigboh, E. U., 1999, Egusi fruit coring machine. J. Agric. Eng. Res. 74: 121-126.

Arabsalmani, K., 1996, Evaluation of flowering, fruiting and effect of seed extraction time on seed quality characters of cantaloupe (cucumis melo), M. Sc., Th., Univ. of Tabriz, Iran: $65-80$.

Awady, M. N., Yehia, I. Hassan, M. A. and El Lithy, A. M., 2004, Some physical and mechanical properties of Minneola fruits, Misr J. Ag. Eng., 21(2): 669-684.

Buyanov, A. I. and Voronyuk, B. A., 1985, Physical and mechanical properties of plants, Fertilizers and Soils, Amerind Pub. Co., PVT, LTD, New Delhi, Bombay, Calcutta, New York: 15 - 97.

El Sayed, G. H., Harb, S., Yehia, I., and Arif, E. M., 2009, Development of an automatic juicer for minneola fruits, Misr J. Ag. Eng., 34(4): 4155-4167.

Ghanbarian, D., Youneji, I., Fallah , S. and Farahadi, A., 2008, Effect of broiler litter on physical properties growth and yield of two cultivars of cantaloupe, Int. J. Agri. and Biology, Iran Int. J. Agri. Biol. 10(6): 697-700.

Hassan, A. A., 1994, Physiology, production and certification of vegetables seeds, $1^{\text {St }}$ Ed., El Dar El Arabia Pub., Cairo, Egypt (in Arabic): 130-137.

Ministry of Agriculture, 2009, Agricultural statistics, Economical Issues Sector, Cairo, Egypt: 84-107.

Mohsenin, N. N., 1986, Physical properties of plant and animal materials, Gordon and Breach Sc. Pub., N. Y. 
Rashidi, M. and Seyfi, K., 2007, Classification of fruit shape in cantaloupe using the analysis of geometrical attributes, World J. of Ag. Sciences, Iran, 3(6): 735-740.

Vergano, P. J., Testion, R. F., Choudhari, A. C. and Newall, W. C., 1992, Peach vibration bruising: The effect of paper and plastic films between peaches, J. of Food Quality 15(3):183-197.

Wilhelm, L. R., Suter, D. A. and Brusewitz, G. H., 2005, Physical properties of food materials, Food and Processing Eng. Tech., ASAE, St. Joseph, Michigen, USA: $75-85$.

Yehia, I., Kabeel, M. H., and Abdel Galeel, M. M., 2009, Physical and mechanical properties of Ponkan mandarin applied to grading machine, Misr J. Ag. Eng. 26(2): 1036-1053.

Yehia, I., Arif. E. M., El Lithy, A. M., Attallah. M., 2010, Physical and mechanical properties of cantaloupe applied to design seedextraction machine, Misr J. Ag. Eng., 35(2): 1036- 1053.

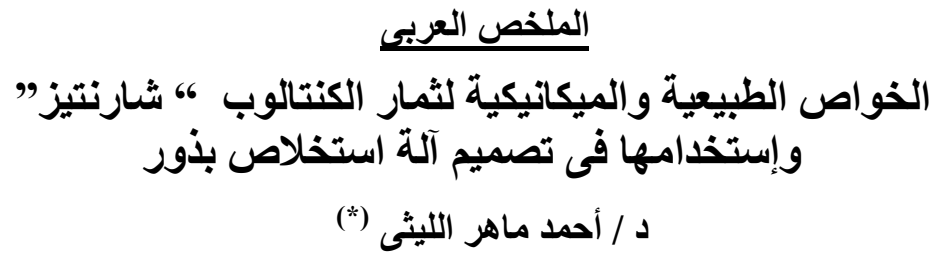

تهدف هذه الدراسة إلى تعيين الخواص الطبيعية والميكانيكية لثمار الكنتالوب صنف "شارنتيز"،

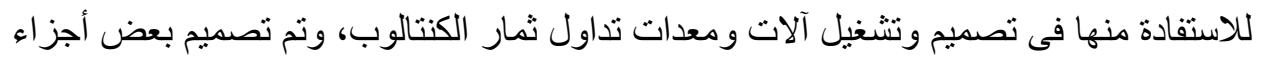

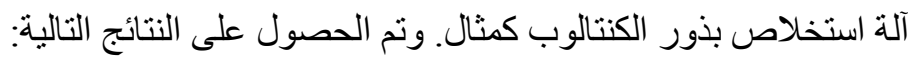

(1) الخواص الطبيعية:

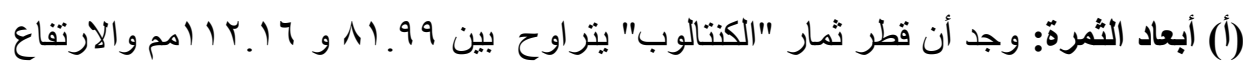

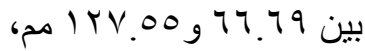

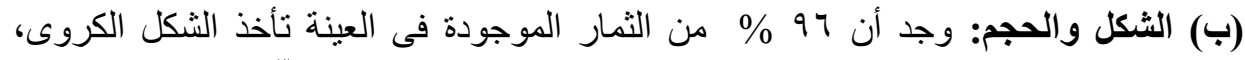

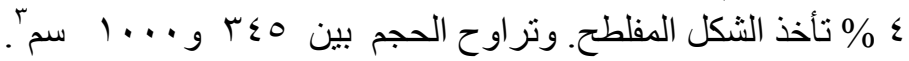

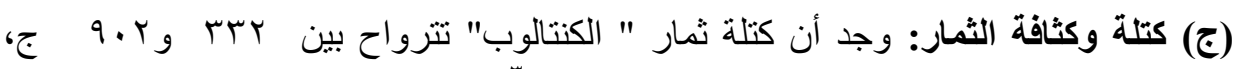

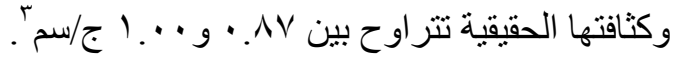

(*) أستاذ الهندسة الزراعية المساعد_ك. الزراعةـ ج. الأزهر- فرع أسيوط. 


\section{PROCESS ENGINEERING}

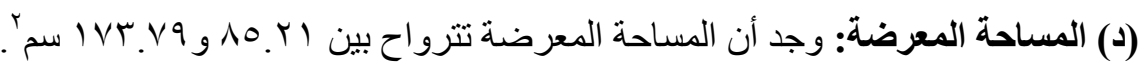
(هـ) عدد البذور لكل ثمرة: وجد أن عدد البذور/الثمرة تراوح بين 9 إ؛ و ال7هـ.

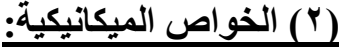

(أ) زاوية الاحتكاك والتدرج والتكويم: وجد أن أقصى زاويتى إحتكاك وتدحرج

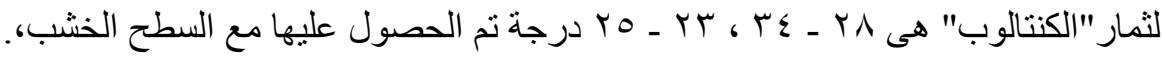

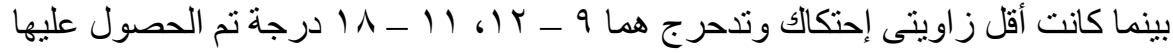

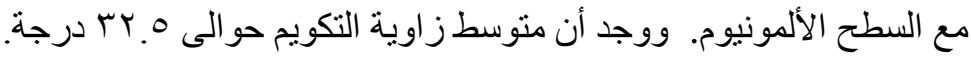

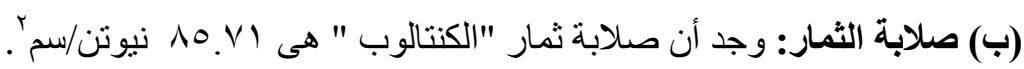
وفى داخل البحث فكرة لتصميم آلة لأستخلاص بذور الكنتالوب باستخدام الخواص الطبيعية و الميكانيكية للثمار. 